\title{
Natronobacillus azotifigens gen. nov., sp. nov., an anaerobic diazotrophic haloalkaliphile from soda-rich habitats
}

\author{
I. D. Sorokin · E. V. Zadorina • I. K. Kravchenko • \\ E. S. Boulygina $\cdot$ T. P. Tourova $\cdot$ D. Y. Sorokin
}

Received: 27 June 2008/Accepted: 17 August 2008/Published online: 4 September 2008

(C) The Author(s) 2008. This article is published with open access at Springerlink.com

\begin{abstract}
Gram-positive bacteria capable of nitrogen fixation were obtained in microoxic enrichments from soda soils in south-western Siberia, north-eastern Mongolia, and the Lybian desert (Egypt). The same organisms were obtained in anoxic enrichments with glucose from soda lake sediments in the Kulunda Steppe (Altai, Russia) using nitrogen-free alkaline medium of $\mathrm{pH} 10$. The isolates were represented by thin motile rods forming terminal round endospores. They are strictly fermentative saccharolytic anaerobes but tolerate high oxygen concentrations, probably due to a high catalase activity. All of the strains are
\end{abstract}

The GenBank accession numbers for the 16S rRNA gene of the novel strains are EU143681-EU143690 and EU850814-EU850816; for the nifH gene the accession numbers are EU542601, EU563380EU563386 and EU850817-EU850819.

Communicated by F. Robb.

Electronic supplementary material The online version of this article (doi:10.1007/s00792-008-0188-0) contains supplementary material, which is available to authorized users.

I. D. Sorokin - I. K. Kravchenko - T. P. Tourova •

D. Y. Sorokin $(\bowtie)$

Winogradsky Institute of Microbiology,

Russian Academy of Sciences,

Prospect 60-let Octyabrya 7/2,

117312 Moscow, Russia

e-mail: soroc@inmi.host.ru; d.y.sorokin@tudelft.nl

E. V. Zadorina $\cdot$ E. S. Boulygina

Bioengineering Centrum RAS,

Prospect 60-let Octyabrya 7/2,

117312 Moscow, Russia

D. Y. Sorokin

Department of Biotechnology,

Delft University of Technology,

Delft, The Netherlands obligately alkaliphilic and highly salt-tolerant natronophiles (chloride-independent sodaphiles). Growth was possible within a $\mathrm{pH}$ range from 7.5 to 10.6 , with an optimum at 9.5-10, and within a salt range from 0.2 to $4 \mathrm{M}$ $\mathrm{Na}^{+}$, with an optimum at $0.5-1.5 \mathrm{M}$ for the different strains. The nitrogenase activity in the whole cells also had an alkaline $\mathrm{pH}$ optimum but was much more sensitive to high salt concentrations compared to the growing cells. The isolates formed a compact genetic group with a high level of DNA similarity. Phylogenetic analysis based on 16SrRNA gene sequences placed the isolates into Bacillus rRNA group 1 as a separate lineage with Amphibacillus tropicus as the nearest relative. In all isolates the key functional nitrogenase gene nifH was detected. A new genus and species, Natronobacillus azotifigens gen. nov., sp. nov., is proposed to accommodate the novel diazotrophic haloalkaliphiles.

Keywords Nitrogen fixation - Soda soils - Soda lakes · Haloalkaliphilic $\cdot$ nifH gene $\cdot$ Bacillus rRNA group 1

\section{Introduction}

Soda-rich habitats are unique saline habitats containing substantial concentrations of sodium carbonates among the dominant soluble salts. They include soda (sodic) soils and soda lakes. They are locally distributed in the dry steppe and semidesert areas, such as south Siberia, north-eastern Mongolia and north China in Central Asia, Egypt, Ethiopia, Kenya and Tanzania in Africa as well as in Armenia, India, Pakistan, western Ukraine, Hungary and eastern North America (Bazilevich 1970; Kondorskaya 1965; Grant 1986; Zavarzin 2007). In contrast to the well-studied soda lakes (Jones et al. 1998; Zavarzin et al. 1999; Sorokin and 
Kuenen 2005), information on microbial diversity and activity in soda solonchaks is very scarce. Most of the studies on saline soils concerned salt-tolerant symbiotic diazotrophs and salt-tolerant plants (Zahran 1997). On top of the high alkalinity and salinity, soda soils are subjected to long periods of desiccation with high aeration, which should lead to a lower diversity of haloalkaliphilic taxa with a domination of spore-forming organisms, such as Gram-positive bacteria, streptomycetes and fungi.

Nitrogen fixation (NF) activity is one of the most important indicators of microbial activity. The evidence for $\mathrm{NF}$ activity in haloalkaline habitats is very scarce. A few studies on NF in soda lakes identified haloalkaliphilic cyanobacteria as the only active diazotrophic group (Oremland 1990; Herbst 1998; Zavarzin et al. 1999) in water. Quite recently the potential of NF was also discovered in a few haloalkaliphilic bacteria isolated from soda lake sediments, such as the aerobic Gammaproteobacteria Thialkalispira microaerophila and Alkalilimnicola halodurans (nifH gene detection) (Tourova et al. 2007) as well as the obligate anaerobes Clostridium alkalicellulosum (Zhilina et al. 2005) and Geoalkalibacter ferrihydritucus (Zavarzina et al. 2006) (activity and nifH detection). Molecular analysis of the nifH gene in brines of the alkaline saline Mono Lake demonstrated a domination of Deltaproteobacteria among the diazotrophic population, although no apparent activity was found under in situ conditions (Steward et al. 2004).

Recently, a potential for nitrogen fixation in soda solonchak soils was detected by our group. The presence of two groups of diazotrophic Gram-positive bacteria in haloalkaliphilic enrichment cultures was identified (Sorokin et al. 2008a). In this paper, a novel branch of obligately fermentative diazotrophic Gram-positive bacteria is described. This branch belongs to the rRNA group 1 of bacilli, which dominate the soda soils and soda lakes of Central Asia and Egypt. The NF potential in this cluster of
low-GC Gram-positive bacteria has never been previously recognized.

\section{Methods}

Samples

Soda solonchak samples used for the enrichments (top $5 \mathrm{~cm}$ ) were obtained from the north-eastern part of Mongolia (Choibalsan Province, 1999), from the Kulunda Steppe (Altai, Russia, 2003) and from Wadi Natrun valley in the Lybian desert (Egypt, 2001). The samples were kept in sterile plastic Petri dishes and stored at $4^{\circ} \mathrm{C}$. The soda lake sediment samples (top $10 \mathrm{~cm}$ of the soil) were taken from three lakes in the south Kulunda Steppe (2007). The chemical properties of the samples are given in Table 1.

Potential nitrogen fixation (NF) activity

Potential NF activity in soils was measured by the acetylene reduction method (Stewart et al. 1968) using $5 \mathrm{~g}$ of sample flooded with $3 \mathrm{ml}$ water in $15 \mathrm{ml}$ serum bottles at 0 , 2 and $20 \% \mathrm{O}_{2}$ in the gas phase. After 2 days of preincubation, $10 \%$ of acetylene in the gas phase and $5 \mathrm{mg}$ of glucose were supplied to start the experiment. The sediments were mixed with near bottom brines or (after removal of the pore brines by centrifugation) with soda buffer ( $\mathrm{pH} \mathrm{10,} \mathrm{same} \mathrm{sodium} \mathrm{concentration} \mathrm{as} \mathrm{in} \mathrm{the} \mathrm{lake}$ brines) at 1:2 ratio and incubated either aerobically or anaerobically with $10 \%$ acetylene and $10 \mathrm{mM}$ of various electron donors. Ethylene production, measured daily by $\mathrm{GC}$, was taken as an indication of the NF potential. The same method was used to measure NF activity in pure cultures, except that in this case acetylene was added after replacement of the gas phase with argon.

Table 1 Characteristics of the samples

\begin{tabular}{|c|c|c|c|c|c|}
\hline Habitat & Sample & Location & $\mathrm{pH}^{\mathrm{a}}$ & $\begin{array}{l}\text { Total soluble } \\
\text { salts }^{\mathrm{b}}(\%)\end{array}$ & $\begin{array}{l}\text { Total soluble } \\
\text { alkalinity }{ }^{\mathrm{c}}(\mathrm{mM})\end{array}$ \\
\hline \multirow[t]{4}{*}{ Soda solonchak soils } & $13 \mathrm{KS}$ & Kulunda Steppe (Altai, Russia) & 9.85 & 5.3 & 50 \\
\hline & $24 \mathrm{KS}$ & & 10.21 & 7.3 & 1,150 \\
\hline & $12 \mathrm{MS}$ & n-e Mongolia & 10.35 & 4.8 & 50 \\
\hline & $3 \mathrm{ES}$ & Wadi Natrun, Egypt & 10.05 & 8.5 & 1,740 \\
\hline \multirow[t]{3}{*}{ Soda lake sediments } & Lake Picturesque (Zh) & Kulunda Steppe (Altai, Russia) & 10.20 & 10.0 & 1,340 \\
\hline & Lake Tanatar-5 (T5) & & 10.35 & 7.0 & 770 \\
\hline & Lake Bitter-1 (B1) & & 10.53 & 17.5 & 2,950 \\
\hline
\end{tabular}

${ }^{\mathrm{a}}$ The $\mathrm{pH}$ of the soil samples was measured in a 1:5 water extract

b $(w / w)$ for the soil samples and (w/v) for the lake brines

c $\mathrm{mmol} \mathrm{kg}^{-1}$ for soils and $\mathrm{mmol}^{-1}$ for lakes 


\section{Cultivation}

The enrichment cultures were started from the activated samples using a $10 \%$ inoculum under microoxic conditions (10 ml medium in $15 \mathrm{ml}$ static flasks with rubber stoppers) at $25^{\circ} \mathrm{C}$ using a nitrogen-free soda medium of the following composition $\left(\mathrm{g} \mathrm{l}^{-1}\right): \mathrm{Na}_{2} \mathrm{CO}_{3} 22-95 ; \mathrm{NaHCO}_{3} 8-15 ; \mathrm{NaCl}$ $6-16 ; \mathrm{K}_{2} \mathrm{HPO}_{4}$ 0.5. The range of the medium components represents a total salt concentration from 0.6 to $2 \mathrm{M} \mathrm{Na}^{+}$. After sterilization (pH of the medium was 10), the medium was supplemented with $1 \mathrm{mM} \mathrm{MgSO}_{4}, 1 \mathrm{ml} \mathrm{l}^{-1}$ of trace metal solution, a vitamin mixture (Pfennig and Lippert 1966), $2 \mathrm{~g} \mathrm{l}^{-1}$ filter-sterilized glucose, and $10 \mathrm{mg} \mathrm{l}^{-1}$ of yeast extract. After the appearance of visible turbidity, NF activity was measured and in the case of positive results the cultures were transferred into fresh medium at 1:100 dilution for several times in order to stabilize. Finally the cultures were serially diluted and the most active dilution (5-6 times) was plated onto solid medium with the same composition, which was prepared by $1: 1$ mixing of doublestrength liquid soda medium and $4 \%$ agar at $50^{\circ} \mathrm{C}$. The plates were incubated in gas-tight jars (Oxoid) under $95 \%$ $\operatorname{argon} / 5 \% \mathrm{~N}_{2}$ atmosphere for $1-2$ weeks at $25^{\circ} \mathrm{C}$. Colonies with different morphology were placed into liquid medium and the resulting cultures were checked for NF potential.

\section{Phenotypic characterization of the pure cultures}

The phenotypic characterization of the isolates included light and electron microscopy, growth experiments to determine the substrate utilization profile (at $\mathrm{pH} 10$ and $0.6 \mathrm{M}$ total $\mathrm{Na}^{+}$) as well as the influence of $\mathrm{pH}$ and salt on the growth and NF activity. For the latter, the cells were grown on standard nitrogen-free medium of $\mathrm{pH} 10$ and consequently centrifuged and washed with $0.5 \mathrm{M} \mathrm{NaHCO}_{3}$ of $\mathrm{pH} 8$ at a protein concentration of $20 \mathrm{mg} \mathrm{ml}^{-1}$. For determining the $\mathrm{pH}$ range of growth, the cells were resuspended at a concentration of $0.3-0.4 \mathrm{mg}$ protein $\mathrm{ml}^{-1}$ in a series of buffers (Sorokin 2005) containing $1.3 \mathrm{M}$ total $\mathrm{Na}^{+}$, while for the salt range tests soda buffer of $\mathrm{pH} 10$ was used at a concentration of $0.1-4 \mathrm{M} \mathrm{Na}^{+}$. The tests were performed in duplicate in $7 \mathrm{ml}$ serum flasks with $3 \mathrm{ml}$ cell suspension under anoxic conditions. The flasks were made anoxic by the replacement of air for argon, after which sodium sulfide $(1 \mathrm{mM})$, glucose $\left(1 \mathrm{mg} \mathrm{ml}^{-1}\right)$ and acetylene $(10 \%$ in the gas phase) were added. Ethylene production was measured every $4 \mathrm{~h}$ by gas chromatography (Chrome-41, Czech Republic; column-Spherosil, $3.2 \mathrm{~m}$; FID detector).

The concentration of cell protein was determined by the Lowry method (Lowry et al. 1951). The catalase activity in washed cells was quantified by using the iodimetric method (Sumner and Dounce 1963). The phospholipid composition was detected by TLC according to Govorukhina and Trotsenko (1989). The fatty acids of the membrane polar lipids were extracted with a mixture of methanol and chloroform and the composition was characterized by GC-MS according to Zhilina et al. (1997). The isomers of diaminopimelic acid (DAP) in the peptidoglycan were determined by TLC on cellulose (Hasegawa et al. 1983). The comparison of total protein content was performed using denaturing gradient electrophoresis according to Laemmli (1970). The final products of the glucose fermentation were detected by HPLC-anionic chromatography using a HPX-87-H column (BioRad) at $60^{\circ} \mathrm{C}$. The products were detected by a UV and RI detector and a $5 \mathrm{mM} \mathrm{H}_{2} \mathrm{SO}_{4}$ solution at $0.6 \mathrm{ml} \mathrm{min}^{-1}$ was used as eluent. The samples were neutralized to $\mathrm{pH} 7$ before analysis.

\section{Genetic analysis}

The isolation of the genomic DNA was performed according to Marmur (1961) and the subsequent determination of the $\mathrm{G}+\mathrm{C}$ content of the DNA and the DNADNA hybridization were carried out by using the thermal denaturation/reassociation technique (De Ley et al. 1970; Marmur and Doty 1962). The $16 \mathrm{~S}$ rRNA genes were amplified by using the universal bacterial primers $11 \mathrm{~F}$ 1492R (Lane 1991) and the fragments of the nifH gene were amplified with the specially designed and previously tested primer pair F1-R6 (Marusina et al. 2001). The PCR products were purified from low-melting agarose using the Wizard PCR-Prep kit (Promega, USA). Sequencing was performed using the Big Dye Terminator v.3.1 sequencing reaction kit using an $\mathrm{ABI} 3730$ DNA automatic sequencer (Applied Biosystems, Inc., USA). Preliminary phylogenetic analysis of the new sequences was performed using the NCBI BLAST server (http://www.ncbi.nlm.nih. gov/BLAST/). The nucleotide and inferred amino acid sequences were aligned with sequences from the GenBank using CLUSTALW. Phylogenic trees were reconstructed using the Neighbor-Joining algorithm within the TREECONW program package (Van de Peer and De Wachter 1994).

\section{Results and discussion}

\section{Potential NF activity}

The acetylene reduction test demonstrated the presence of a diazotrophic community in all the four investigated soda solonchak samples with potential NF activity ranging from 16 to $80 \mathrm{nmol} \mathrm{N}(\mathrm{g} \mathrm{h})^{-1}$. However, the activity started to manifest itself only after a 2-3-day lag phase indicating either a low initial number of active diazotroph cells or 
their dormant state (spores). The activity was inhibited at fully aerobic conditions and was almost equal at microoxic ( $2 \%$ oxygen) and anoxic conditions.

The NF potential was measurable directly only in the soda lake sediments of Lake Picturesque (low sulfide sediments), while in the other two lakes (high sulfide sediments) the activity manifested itself only after removal of the pore brines. A qualitative ammonium test (Merck) was positive in the latter and negative for the Picturesque Lake sediments, which might explain the results. Perhaps, the absence of the NF activity reported recently for the Mono Lake anoxic waters (Steward et al. 2004) was also the result of a blockade by bound nitrogen. The potential NF activity in the unblocked lake sediments under dark anaerobic conditions with glucose was within the range of 2-30 nmol $\mathrm{N}(\mathrm{g} \mathrm{h})^{-1}$. The NF activity in the sediments clearly belonged to an obligately alkaliphilic population (Fig. 1a) with only a moderate salt tolerance (Fig. 1b).
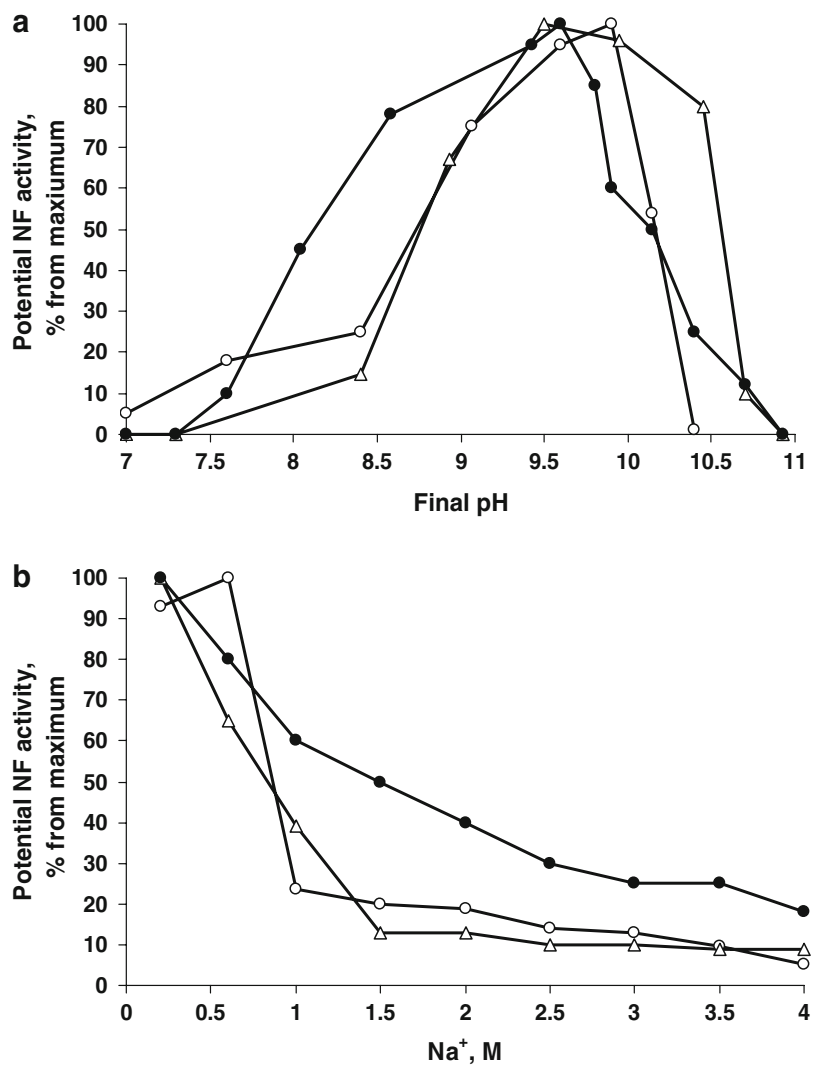

Fig. 1 The influence of $\mathrm{pH}$ at native salinity (a) and sodium carbonates at $\mathrm{pH} 10(\mathbf{b})$ on potential NF activity under dark anoxic conditions in sediment slurries ( 1 part sediment/2 parts buffer) from soda lakes. The activity was measured after removal of the pore brines and resuspension of the solids in anaerobic buffers. $0.1 \mathrm{M}$ $\mathrm{HEPES} / \mathrm{NaCl}$ was used for the $\mathrm{pH}$ range from 6 to 8 and $\mathrm{NaHCO}_{3} /$ $\mathrm{Na}_{2} \mathrm{CO}_{3}$ for the $\mathrm{pH}$ range from 8 to 11.5 . The $\mathrm{pH}$ was adjusted by $1 \mathrm{M}$ $\mathrm{HCl}$ or $\mathrm{NaOH}$ before the experiment and the final $\mathrm{pH}$ values were taken as the incubation $\mathrm{pH}$. Incubation time was $24 \mathrm{~h}$. $100 \%$ activity, $\mathrm{nmol} \mathrm{N} /\left(\mathrm{cm}^{3} \mathrm{~h}\right)^{-1}$ : Picturesque lake (closed circles $)=9$; Tanatar-5 $($ open circles $)=2 ;$ Bitter-1 $($ open triangles $)=37$
Enrichment and isolation of the diazotrophic haloalkaliphiles

In the microoxic (soils) and anoxic (lake sediments) enrichment cultures $(\mathrm{pH} 10$, salt concentration equivalent to 0.6-2 $\mathrm{M}$ total $\mathrm{Na}^{+}$) with glucose, Gram-positive endosporeforming bacteria were obviously dominating. However, most of them were apparently not diazotrophic, despite the absence of bound nitrogen in the medium. In the serial dilutions made from the primary enrichments, growth was observed up to $(-9)-(-10)$ dilution, while the acetylene reduction stopped already at $(-6)-(-7)$ dilution. Hence, the isolation of pure cultures on plates was not straigtforward. Of more than a hundred colonies obtained from seven enrichments only eleven resulted in active diazotrophic cultures.

Properties of the haloalkaliphilic diazotrophs

All of the diazotrophic cultures were represented by Grampositive, thin and slightly curved rods of variable length. The rods were motile with peritrichous flagella and usually formed round terminal endospores (Fig. 2). They had a fluffy polysaccharide matrix in the concentrated cell pellets and a yellow pigmentation of a varied intensity. The latter was due a presence of methanol-extractable pigment, which on basis of its spectrum (maximum at $435 \mathrm{~nm}$ and shoulders at 407 and $465 \mathrm{~nm}$ ) resembled a novel $\mathrm{C}_{20}$ xanthine-like chromophore recently described for the extremely natronophilic strains of the genus Thioalkalivibrio (Takaichi et al. 2004).

All of the strains were strictly fermentative anaerobes using various simple carbohydrates, but they could tolerate fully aerobic conditions and continued to ferment glucose even after being placed in shaking flasks. This observation is probably due to a relatively high catalase activity in the organism [0.2-0.4 U (mg protein $\left.)^{-1}\right]$. The growth rate under aerobic conditions was equal to that of the anaerobic cultures but the final growth yield was two times lower at forced aeration, indicating that some inhibition of growth had taken place. The respiration test with washed cells showed no glucose-stimulated oxygen consumption. The final fermentation products from glucose were ethanol, acetate and formate. Cytochromes were not detectable by spectrophotometer in the cell-free extracts. One of the striking features of the novel isolates was their extraordinary sulfide tolerance. During the anaerobic growth at $\mathrm{pH} 10$ with glucose all strains tolerated up to $100-120 \mathrm{mM}$ of sulfide.

The analysis of phospholipids in strain $24 \mathrm{KS}-1^{\mathrm{T}}$ grown at $0.6 \mathrm{M}$ of total $\mathrm{Na}^{+}, \mathrm{pH} 10$ and $30^{\circ} \mathrm{C}$ demonstrated the presence of phosphatidic acid, phosphatidylethanolamine and phosphatidylglycerol (cardiolipin) as major components as well as several minor unidentified phospholipids. Fatty acid analysis of the polar lipids in the same strain showed a profile typically found in bacilli with a domination of 
Fig. 2 The cell morphology of diazotrophic strains from soda soils grown with glucose at $\mathrm{pH}$ 10. a-d Phase contrast micrographs (a strain $24 \mathrm{KS}-1^{\mathrm{T}}$; b strain MS4-1; c strain T5-1; d strain B1-3d); e electron micrograph of a total preparation, strain $24 \mathrm{KS}-1^{\mathrm{T}}$ (bar $1 \mu \mathrm{m}$ ); $\mathbf{f}$ thin section, strain $24 \mathrm{KS}-1^{\mathrm{T}}$ (bar $\left.0.5 \mu \mathrm{m}\right)$
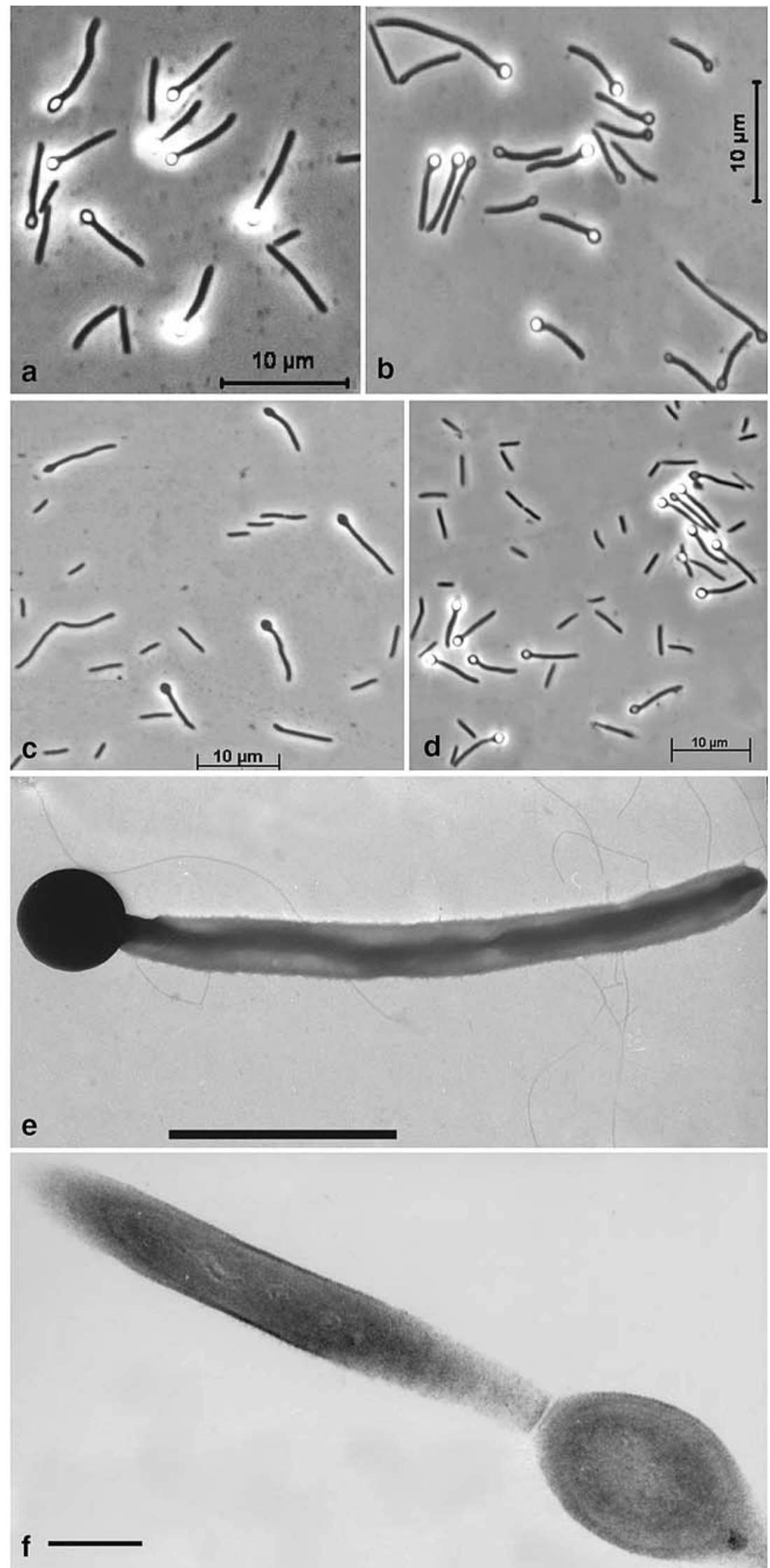
saturated species, such as anteiso $C_{15: 0}$, iso $C_{15: 0}$ and $\mathrm{C}_{16: 0}$ (supplementary Table). Analysis of the respiratory quinones in strain $24 \mathrm{KS}-1^{\mathrm{T}}$ gave negative results, probably due to the strict fermentative nature of this bacterium. The cell wall analysis demonstrated a presence of meso-DAP as a diagnostic diaminoacid in its peptidoglycan.

The behavior under different $\mathrm{pH}$ and salt conditions, especially of the nitrogenase activity, of the new isolates was of special interest. The growth and activity experiments demonstrated that all of the isolates were obligately alkaliphilic and extremely natrono(soda)-tolerant (Fig. 3). However, the isolates did not depend on chloride, which is a typical trait for the bacteria isolated from soda-rich habitats. Surprisingly, despite the fact that both the nitrogenase and fermentation enzymes are intracellular, both systems reacted to changes in $\mathrm{pH}$ in the same way as the growing cultures, i.e. exhibited alkaliphilic profiles (Fig. 3a). However, the nitrogenase activity was much more sensitive to salt inhibition than the cultures growing in the presence of organic nitrogen (Fig. 3b). Both the $\mathrm{pH}$ profile and the salt profile for the nitrogenase activity corresponded well to that which was observed in the sediment slurry experiments (see Fig. 1).
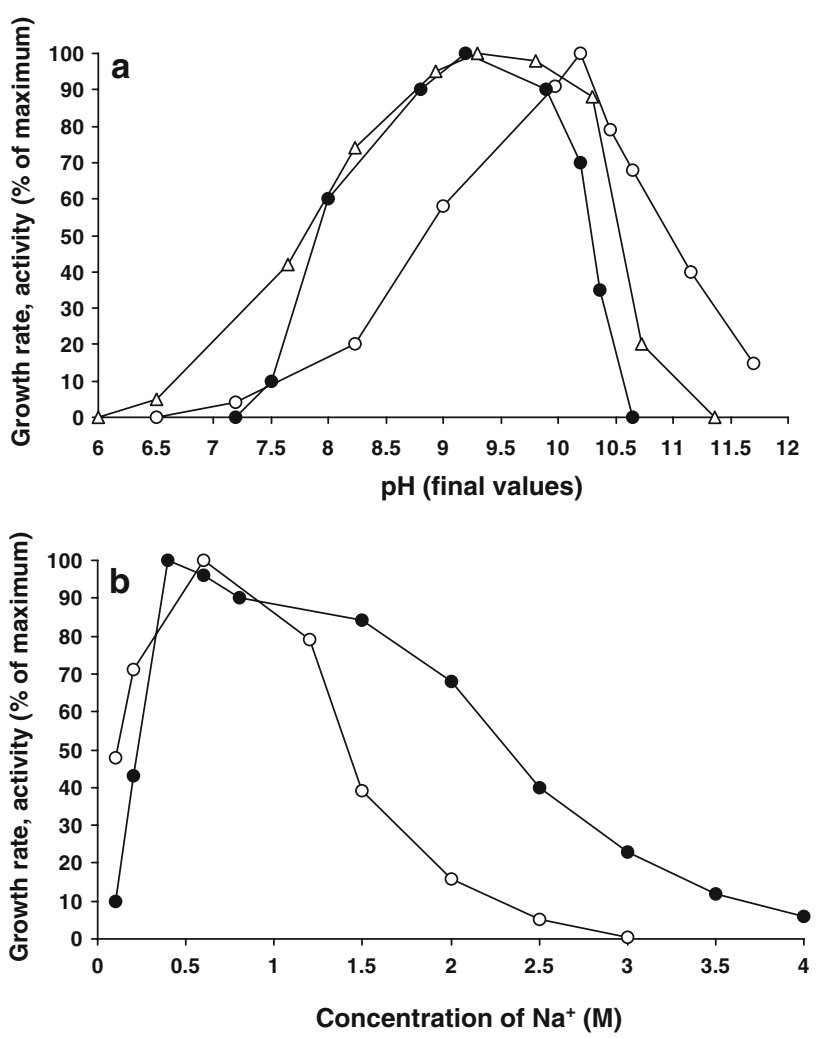

Fig. 3 The influence of $\mathrm{pH}$ at $1.3 \mathrm{M} \mathrm{Na}^{+}$(a) and of sodium at $\mathrm{pH} 10$ (b) on the fermentative growth and the activity of washed cells of strain $24 \mathrm{KS}-1^{\mathrm{T}}$ with glucose. Closed circles growth rate, open circles nitrogenase activity in washed cells, open triangles activity of glucose uptake by washed cells
Identification of the haloalkaliphilic diazotrophs

Phylogenetic analysis based on sequencing of the 16S-rRNA gene placed the isolates into the rRNA group 1 of bacilli (Nielsen et al. 1994) (Fig. 4a). The strains formed a compact group with almost identical sequences (99-99.7\%) and were clustering (96.0-96.6\% of sequence similarity) with Amphibacillus tropicus, which is an aerotolerant fermentative haloalkaliphile from soda lakes (Zhilina et al. 2001). The diazotrophic isolates had a 70-93\% DNA-DNA similarity as well as similar, but not identical, total protein profiles (supplementary Fig. 1), which indicates that they belong to a single genetic species. On the other hand, the isolates had only a $30-35 \%$ DNA similarity (strains $24 \mathrm{KS}-1^{\mathrm{T}}$, MS5, ES3 and T5-3) with A. tropicus.

From the tree topology and the sequence distances, it is quite clear that the genus Amphibacillus in its present form needs a revision. The type species $A$. xylanus, $A$. fermentum, $A$. sediminis and several undescribed isolates from saline lakes form the core group of the genus, while A. tropicus and the novel diazotrophic haloalkaliphiles from soda habitats form a separate generic lineage with only 91-93\% sequence similarity to the core group. Another closely related group to the novel isolates with $16 \mathrm{~S}$ rRNA gene sequence similarity of around $95 \%$ is the genus Halolactibacillus (Ishikawa et al. 2005), accommodating alkali- and halo-tolerant marine fermentative bacteria. A phenotypic comparison of the novel diazotrophs with their closest phylogenetic relatives is given in Table 2. Assuming the close relation of the novel diazotrophs to the Amphibacillus species, the ability to fix $\mathrm{N}_{2}$ was also tested in the latter (A. tropicus and A. fermentum), but without success.

\section{nif $\mathrm{H}$ detection}

Functional gene analysis demonstrated the presence of the nifH gene (coding for the nitrogenase-reductase subunit of nitrogenase) in all of the diazotrophic isolates but not in their haloalkaliphilic relatives (A. tropicus and A. fermentum). The sequences had a very high similarity level $(>95 \%)$ and formed a separate cluster related to the nifH gene of a recently described Bacillus alkalidiazotrophicus MS 6, which is a novel diazotrophic representative of the RNA group 6 of bacilli from the Mongolian soda soil, and its closest haloalkaliphilic relative $B$. arseniciselenatis (Sorokin et al. 2008 b) (Fig. 4b). This alkaliphilic cluster formed a novel deep lineage within the nifH gene family related to Paenibacillus and cyanobacteria. It is remarkable that the only group of bacilli containing diazotrophic species is currently confined within the aerobic genus Paenibacillus (Achouak et al. 1999). Apparently, there is more to the ability of the Gram-positive bacteria (other than clostridia) to fix nitrogen than is currently recognized. 
Fig. 4 The phylogenetic position based on the 16S rRNA gene sequence analysis (a) and inferred aminoacid sequence analysis of the nifH gene (b) of the diazotrophic haloalkaliphilic isolates. Tree topography and evolutionary distances are given by the neighbor-joining method with Jukes and Cantor corrections. Numbers at the nodes indicate the percentage of bootstrap values for the clade of this group in 1,000 replications
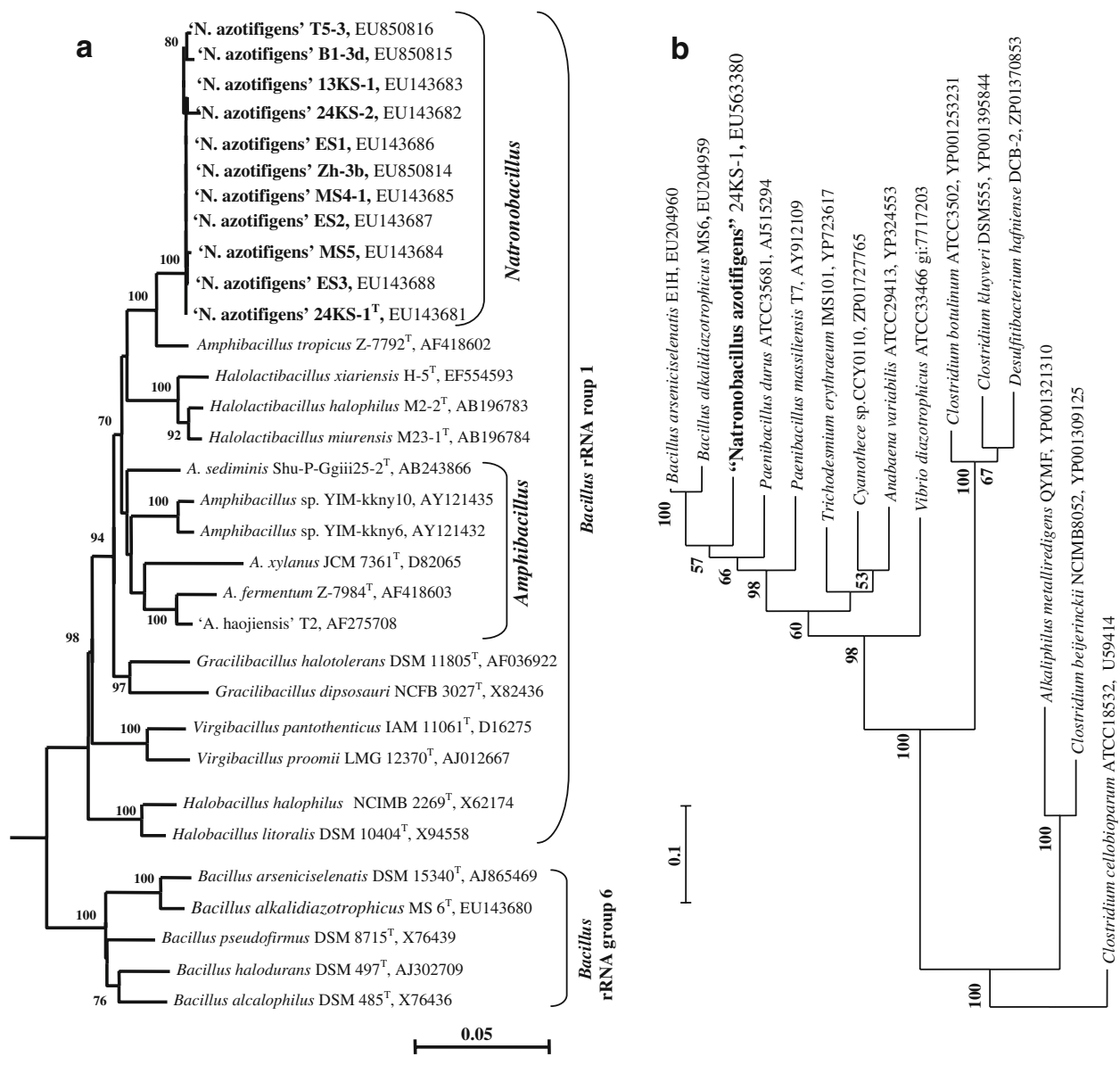

Concluding, the results indicate the presence of an active population of fermentative diazotrophs in extremely haloalkaline habitats from different geographical locations, which forms a novel phylogenetic lineage within the rRNA group 1 of bacilli. These bacteria are extremely salt tolerant obligate alkaliphiles able to grow in saturated soda brines. The nitrogen fixation activity is active up to $2 \mathrm{M}$ total $\mathrm{Na}^{+}$ at $\mathrm{pH} 10$. These conditions were not reported so far for any other diazotrophs. Based on the phenotypic and genetic comparison, the new haloalkaliphilic diazotrophic members of the rRNA group 1 of bacilli from soda-rich habitats are proposed to be accommodated by a new genus and species Natronobacillus azotifigens gen. nov., sp. nov.

\section{Description of Natronobacillus gen. nov.}

(N.Gr. n. natron, arbitrarily derived from the Arabic n. natrun or natron, soda; L. masc. n. bacillus, a small rod; N.L. masc. n. Natronobacillus soda-loving rod)

Rod-shaped, motile, endospore-forming bacterium with obligately fermentative metabolism. Aerotolerant and extremely sulfide-tolerant. Cells contain yellow pigment. Fatty acids of the polar lipids are dominated by saturated
$\mathrm{C}_{15}-\mathrm{C}_{16}$ species. Peptidoglycan contains meso-DAP. Diazotrophic. Obligately alkaliphilic and extremely salttolerant. Natronophilic (soda-loving) and chloride-independent. Utilizes simple carbohydrates and some natural polymers, such as starch, xylan and glycogen. A member of the rRNA group 1 of bacilli with low $\mathrm{G}+\mathrm{C}$ content. Habitats-soda soils and soda lake sediments. The type species is Natronobacillus azotifigens.

\section{Description of Natronobacillus azotifigens sp. nov.}

(a.zo.ti.f'gens N.L. n. azotum (from Fr. n. azote), nitrogen; L. part. adj. figens, fixing, attaching; N.L. part. adj. azotifigens, nitrogen-fixing)

Cells are Gram-positive, thin and curved rods of $0.4-0.5 \times 2.0-6.0 \mu \mathrm{m}$, motile with peritrichous flagella. Cells contain yellow membrane-bound pigment with an absorption maximum at $435 \mathrm{~nm}$. The dominant phospholipids include phosphatidic acid, phosphatidylethanolamine and phosphatidilglycerole. The dominant cellular fatty acids are $\mathrm{aiC}_{15: 0}, \mathrm{iC}_{15: 0}, \mathrm{aiC}_{13: 0}, \mathrm{C}_{16: 0}, \mathrm{aiC}_{17: 0}$ and $\mathrm{iC}_{13: 0}$. Strictly fermentative but aerotolerant anaerobe. Extremely sulfide-tolerant. The following carbohydrates can be 
Table 2 The properties of the diazotrophic strains from soda habitats compared to those of the closest relatives from Bacillus rRNA group 1

\begin{tabular}{|c|c|c|c|c|}
\hline Property & 1 & 2 & 3 & 4 \\
\hline Cell morphology & Long curved rods & Long curved rods & Short straight rods & Long curved rods \\
\hline Endospores & + & + & - & - \\
\hline Yellow pigment & + & - & - & - \\
\hline $\begin{array}{l}\text { Dominant fatty acids in polar } \\
\text { lipids }\end{array}$ & $\begin{array}{l}\operatorname{aiC}_{15: 0}, \mathrm{iC}_{15: 0}, \mathrm{aiC}_{13: 0}, \\
\quad \mathrm{C}_{16: 0},\end{array}$ & $\begin{array}{l}\operatorname{aiC}_{15: 0}, \mathrm{iC}_{15: 0}, \mathrm{C}_{16: 0} \\
\quad \mathrm{iC}_{13: 0}\end{array}$ & $\mathrm{C}_{16: 0}$, aiC $_{13: 0}, \mathrm{C}_{15: 0}$ & $\begin{array}{l}\operatorname{aiC}_{15: 0}, C_{16: 0}, \mathrm{iC}_{15: 0}, \mathrm{aiC}_{17: 0}, \\
\quad \mathrm{C}_{15: 0}\end{array}$ \\
\hline Fermentative growth & Obligate & Obligate & Obligate & Aerobe \\
\hline Main fermentation products & Acetate, formate, ethanol & $\begin{array}{l}\text { Acetate, formate, } \\
\text { ethanol }\end{array}$ & $\begin{array}{l}\text { Lactate, acetate, formate, } \\
\text { ethanol }\end{array}$ & - \\
\hline Catalase & + & + & - & + \\
\hline Nitrogen fixation & + & - & ND & ND \\
\hline Alkaliphility & Obligate & Obligate & Facultative & Tolerance \\
\hline $\mathrm{Na}^{+} \mathrm{M}$ range, (optimum) & $0.2-4.0(1.0-1.5)$ & $0.2-3.6(1.0-1.9)$ & $0-4.1(0.5)$ & $0-2.7(0)$ \\
\hline $\mathrm{Na}^{+}$-dependence & + & + & - & - \\
\hline $\mathrm{Cl}^{-}$-dependence & - & - & + & + \\
\hline Nitrate reduction & - & - & + & + \\
\hline Utilization of pentoses & D-Ribose, D-xylose & D-Xylose & D-Ribose & D-Xylose \\
\hline $\begin{array}{l}\text { Utilization of } N \text {-acetyl- } \\
\text { glucosamine }\end{array}$ & - & - & ND & + \\
\hline Polymer hydrolysis & Starch, xylan, glycogen & Starch, xylan, glycogen & Starch & Starch, glycogen, gelatin \\
\hline Hydrolysis of Tween- 80 & - & - & ND & + \\
\hline $\begin{array}{l}\mathrm{G}+\mathrm{C} \text { in the DNA, mol\% } \\
(\mathrm{Tm})\end{array}$ & $36.1-37.2$ & 39.2 & 38.5 & 38.0 \\
\hline Isolated from: & Soda soils and lakes & $\begin{array}{l}\text { Soda Lake Magadi } \\
\text { (Kenya) }\end{array}$ & Sea water & Great Salt Lake \\
\hline
\end{tabular}

1 Natronobacillus azotifigens 24KS-1 $\%$ /ES1/T5-1, 2 Amphibacillus tropicus (Zhilina et al. 2001), 3 Halolactibacillus halophilus (Ishikawa et al. 2005), 4 Gracilibacillus halotolerans (Wainø et al. 1999)

$N D$ not determined

fermented: glucose, fructose, maltose, xylose, galactose, sucrose, cellobiose, raffinose (some strains), and weakly: ribose, lactose, mannose, melibiose, melizitose and arabinose. Able to hydrolyze and utilize starch, xylan and glycogen. Glucose is fermented to acetate, ethanol and formate. Diazotrophic. Obligate alkaliphile with a $\mathrm{pH}$ range for growth between 7.5 and 10.6 (optimum 9.5-10) and a salt range from 0.2 to $4 \mathrm{M} \mathrm{Na}{ }^{+}$(optimum 1.0-1.5 M). Mesophilic with an optimum temperature for growth at $36-38^{\circ} \mathrm{C}$. The $\mathrm{G}+\mathrm{C}$ content in the genomic DNA is $36.1-38.5 \mathrm{~mol} \%$ (Tm). Isolated from soda solonchak soils and soda lake sediments in Central Asia and Egypt.

The type strain is $24 \mathrm{KS}-1^{\mathrm{T}}\left(\mathrm{NCCB} 100215^{\mathrm{T}}=\mathrm{UNIQEM}\right.$ $\mathrm{U}_{378^{\mathrm{T}}}$ ). Isolated from soda soils in the Kulunda Steppe (Altai, Russia). The $\mathrm{G}+\mathrm{C}$ content in the genomic DNA of the type strain is $36.1 \mathrm{~mol} \%$ (Tm). The Gen Bank accession number of the 16S-rRNA gene and nifH gene sequences of the type strain are EU143681 and EU563380, respectively.

Acknowledgments This work was supported by NWO-RFBR (grant 047.011.2004.010, RFBR grant 07-04-00153) and by the Program on Molecular and Cell Biology RAS. We are grateful to T. Zhilina for providing the Amphibacillus strains, and to B. Baskunov, L. Evtushenko and Yu. Trotsenko for the chemotaxonomic analyses.

Open Access This article is distributed under the terms of the Creative Commons Attribution Noncommercial License which permits any noncommercial use, distribution, and reproduction in any medium, provided the original author(s) and source are credited.

\section{References}

Achouak W, Normand P, Heulin T (1999) Comparative phylogeny of rrs and nifH genes in the Bacillaceae. Int $\mathrm{J}$ Syst Bacteriol 49:961-967

An S-Y, Ishikawa S, Kasai H, Goto K, Yokoto A (2007) Amphibacillus sediminis sp. nov., an endosporeforming bacterium isolated from lake sediment in Japan. Int J Syst Evol Microbiol 57:2489-2492

Bazilevich NI (1970) The geochemistry of soda soils. USDA, NSF and Israel Program for Scientific Translations. Jerusalem, 396 p. 
De Ley J, Caffon H, Reinaerts A (1970) The quantitative measurements of hybridisation DNA from renaturation rates. Eur $\mathbf{J}$ Biochem 12:133-140

Hasegawa T, Takizawa M, Tanida S (1983) A rapid analysis for chemical grouping of aerobic actinomycetes. J Gen Appl Microbiol 29:319-322

Herbst DB (1998) Potential salinity limitations of nitrogen fixation in sediments from Mono Lake. Int J Salt Lake Res 7:261-274

Govorukhina NI, Trotsenko YA (1989) Phospholipid composition of methylotrophic bacteria. Microbiology (Moscow, English Translation) 58:318-323

Grant WD, Tindall BJ (1986) The alkaline saline environment. In: Herbert RA, Codd GA (eds) Microbes in extreme environments. Academic Press, London, UK, pp 25-54

Ishikawa M, Nakajima K, Itamiya Y, Furukawa S, Yamamoto Y, Yamasato K (2005) Halolactibacillus halophilus gen. nov., sp. nov. and Halolactibacillus miurensis sp. nov., halophilic and alkaliphilic marine lactic acid bacteria constituting a phylogenetic lineage in Bacillus rRNA group 1. Int $\mathrm{J}$ Syst Evol Microbiol 55:2427-2439

Jones BE, Grant WD, Duckworth AW, Owenson GG (1998) Microbial diversity of soda lakes. Extremophiles 2:191-200

Kondorskaya NI (1965) Geographic distribution of soda soils in USSR. Soil Sci 9:10-16 (Moscow, in Russian)

Laemmli UK (1970) Cleavage of structural proteins during the assembly of the head of bacteriophage T4. Nature 227:680-685

Lane DJ (1991) 16S/23S rRNA sequencing. In: Stackebrandt E, Goodfellow $M$ (eds) Nucleic acid techniques in bacterial systematics. Wiley, Chichester, UK, pp 115-177

Lowry OH, Rosebrough NJ, Farr AL, Randall RJ (1951) Protein measurement with the Folin phenol reagent. J Biol Chem 193:265-275

Marmur J (1961) A procedure for isolation of DNA from microorganisms. J Mol Biol 3:208-214

Marmur J, Doty P (1962) Determination of the base composition of deoxyribonucleic acid from microorganisms. J Mol Biol 5:109118

Marusina AI, Boulygina ES, Kuznetsov BB, Tourova TP, Kravchenko IK, Galchenko VF (2001) System of oligonucleotide primers for amplification of nifH genes in diverse groups of Prokaryotes. Microbiology (Moscow, English Translation) 70:86-91

Nielsen P, Rainey FA, Outtrup H, Priest FG, Dagmar F (1994) Comparative 16S rDNA sequence analysis of some alkaliphilic bacilli and the establishment of a sixth rRNA group within the genus Bacillus. FEMS Microbiol Lett 117:61-66

Oremland RS (1990) Nitrogen fixation of two diazotrofic communities in Mono Lake. Appl Environ Microbiol 56:614-622

Pfennig N, Lippert KD (1966) Über das Vitamin $B_{12}$-Bedürfnis phototropher Schwefelbakterien. Arch Microbiol 55:245-256

Sorokin DYu (2005) Is there a limit for high-pH growth? Int J Syst Evol Microbiol 55:1405-1406

Sorokin DYu, Kuenen JG (2005) Haloalkaliphilic sulfur-oxidizing bacteria in soda lakes. FEMS Microbiol Rev 29:685-702

Sorokin ID, Kravchenko IK, Doroshenko EV, Boulygina ES, Zadorina EV, Tourova TP, Sorokin DYu (2008a) Haloalkaliphilic diazotrophs in soda solonchak soils. FEMS Microbiol Ecol 65:425-433
Sorokin ID, Kravchenko IK, Tourova TP, Kolganova TV, Boulygina ES, Sorokin DYu (2008b) Bacillus alkalidiazotrophicus sp. nov., a diazotrophic, low salt-tolerant alkaliphile from Mongolian soda soil. Int J Syst Evol Microbiol 58 (in press)

Steward GF, Zehr JP, Jellison R, Montoya JP, Hollibaugh JT (2004) Vertical distribution of nitrogen-fixing phylotypes in a meromictic, hypersaline lake. Microb Ecol 47:30-40

Stewart WDP, Fitzerald GP, Burris RH (1968) Acetylene reduction by nitrogen fixing blue-green algae. Arch Mikrobiol 62:336-348

Sumner JB, Dounce AL (1963) Liver catalase. Methods Enzymol 63:780

Takaichi S, Maoka T, Akimoto N, Sorokin DYu, Banciu H, Kuenen JG (2004) Two novel yellow pigments natronochrome and chloronatronochrome from the natrono(alkali)philic sulfur-oxidizing bacterium Thialkalivibrio versutus ALJ 15. Tetrahedron Lett 45:8303-8305

Tourova TP, Spiridonova EM, Berg IA, Slobodova NV, Boulygina ES, Sorokin DYu (2007) Phylogeny and evolution of the family Ectothiorhodospiraceae based on comparison of 16S rRNA, $c b b \mathrm{~L}$, and nifH genes. Int J Syst Evol Microbiol 57:2387-2398

Van de Peer Y, De Wachter R (1994) TREECON for Windows: a software package for the construction and drawing of evolutionary trees for the Microsoft Windows environment. Comput Appl Biosci 10:569-570

Wain $\varnothing$ M, Tindall BJ, Schumann P, Ingvorsen K (1999) Gracilibacillus gen. nov., with description of Gracilibacillus halotolerans gen. nov., sp. nov.; transfer of Bacillus dipsosauri to Gracilibacillus dipsosauri comb. nov., and Bacillus salexigens to the genus Salibacillus gen. nov., as Salibacillus salexigens comb. nov. Int J Syst Bacteriol 49:821-831

Zahran HH (1997) Diversity, adaptation and activity of the bacterial flora in saline environments. Biol Fertil Soils 25:211-223

Zavarzin GA (2007) Development of soda environments as a global process. In: Proceedings of Winogradsky Institute of Microbiology, V.XIV. Nauka, Moscow, pp 8-56 (in Russian)

Zavarzina DG, Kolganova TV, Bulygina ES, Kostrikina NA, Tourova TP, Zavarzin GA (2006) Geoalkalibacter ferrihydriticus gen. nov. sp. nov., the first alkaliphilic representative of the family Geobacteraceae isolated from a soda lake. Microbiology (Moscow, English translation) 75:673-682

Zavarzin GA, Zhilina TN, Kevbrin VV (1999) The alkaliphilic microbial community and its functional diversity. Microbiology (Moscow, English Translation) 68:503-521

Zhilina TN, Garnova ES, Tourova TP, Kostrikina NA, Zavarzin GA (2001) Amphibacillus fermentum sp. nov. and Amphibacillus tropicus sp. nov., new alkaliphilic, facultatively anaerobic bacilli from lake Magadi. Microbiology (Moscow, English Translation) 70:711-722

Zhilina TN, Kevbrin VV, Tourova TP, Lysenko AM, Kostrikina NA, Zavarzin GA (2005) Clostridium alkalicellum sp. nov., an obligately alkaliphilic cellulolytic bacterium from a soda lake in the Baikal Region. Microbiology (Moscow, English translation) 74:642-653

Zhilina TN, Zavarzin GA, Rainey FA, Pikuta EN, Osipov GA, Kostrikina NA (1997) Desulfonatronovibrio hydrogenovorans gen. nov., sp. nov., an alkaliphilic, sulfate-reducing bacterium. Int J Syst Bacteriol 47:144-149 